\title{
KINERJA ORGANISASI KEMAHASISWAAN HUBUNGANNYA DENGAN TERMINOLOGI HUMAN CAPITAL
}

\author{
Dese Setyowulan', Nadia Tri Asfa Lia², Rafidah Azizah³, Asep Sunandar4, Maulana \\ Amirul Adha ${ }^{5}$ \\ Jurusan Administrasi Pendidikan Fakultas Ilmu Pendidikan \\ Universitas Negeri Malang; Jln Semarang No. 5 Malang \\ e-mail: 1setiyowulan26@gmail.com,2nadiatriasfalia@gmail.com, \\ 3rafidahazizah19@gmail.com, 4asep.sunandar.fip@um.ac.id, \\ 5amirulmaulana1013@gmail.com
}

Abstract. This study aims to determine, 1) the level of human capital of student organizations, (2) the level of student organization performance, (3) the relationship of human capital to the performance of student organizations in the Faculty of Education (FIP) Malang State University (UM). This research uses a quantitative approach with a descriptive correlational research design. The research instrument used was a questionnaire with respondent members of student organizations in FIP UM. The analysis technique used in this research is descriptive analysis and correlation. The results of this study indicate: (1) the level of human capital of student organizations in the Faculty of Education UM is quite good; (2) the level of performance of student organizations in the Faculty of Education UM is quite good and (3) there is a positive and significant relationship between human capital on the performance of student organizations in the Faculty of Education, State University of Malang.

Keywords. Human capital, Performance, Student organizations

Abstrak. Penelitian ini bertujuan untuk mengetahui, 1) tingkat human capital organisasi mahasiswa, (2) tingkat kinerja organisasi mahasiswa, (3) hubungan human capital terhadap kinerja organisasi mahasiswa yang ada di Fakultas Ilmu Pendidikan (FIP) Universitas Negeri Malang (UM). Penelitian ini menggunakan pendekatan kuantitatif dengan rancangan penelitian bersifat deskriptif korelasional. Instrumen penelitian yang digunakan yakni angket dengan responden anggota organisasi mahasiswa yang ada di FIP UM. Teknik analisis yang digunakan dalam penelitian ini ialah analisis deskriptif dan korelasi. Hasil penelitian ini menunjukkan: (1) tingkat human capital organisasi mahasiswa di Fakultas Ilmu Pendidikan UM tergolong cukup baik; (2) tingkat kinerja organisasi mahasiswa di Fakultas Ilmu Pendidikan UM tergolong cukup baik dan (3) ada hubungan positif dan signifikan antara human capital terhadap kinerja organisasi mahasiswa yang ada di Fakultas Ilmu Pendidikan, Universitas Negeri Malang.

Kata Kunci. Human capital, Kinerja, Organisasi Kemahasiswaan

Copyright (C JMPI: Jurnal Manajemen Pendidikan Islam. All Right Reserved.

This is an open access article under the CC BY-NC-ND license

(http://creativecommons.org/licenses/by-nc-nd/4.0/).

\section{A. PENDAHULUAN}

Organisasi saat ini memerlukan kualitas SDM yang memadai. SDM yang berkontribusi terhadap organisasi dengan memberikan pengetahuan, ide dan kompetensi yang dimiliki secara tidak langsung juga meningkatkan kinerja organisasi. SDM sebagai human capital dianggap memiliki peranan yang penting dikarenakan SDM 
merupakan faktor utama penggerak dalam sebuah organisasi. Aset tak berwujud khususnya kualitas modal manusia merupakan faktor penentu keberhasilan organisasi dalam mencapai kinerja superior, sebab dengan modal manusia yang berkualitas, maka dapat menciptakan organisasi unggul yang berdampak pada peningkatan daya saing organisasi (Tan, 2014).

Mengingat peran SDM yang begitu besar dalam suatu organisasi, maka, manajemen organisasi harus lebih proaktif menjadikan SDM-nya sebagai human capital yang perlu diperhatikan dan dilakukan pengembangan secara kontinyu sesuai dengan kedinamisan lingkungan sekitar (Marginson, 2019). Dapat diketahui bahwa organisasi yang memiliki kinerja baik juga didukung oleh human capital dengan pengetahuan dan keterampilan tinggi pula. Pengetahuan yang dimiliki oleh SDM sebagai human capital yakni dapat digunakan oleh organisasi dalam proses peningkatan kinerja organisasi dimana SDM akan terus berkembang dengan pengetahuan yang mereka miliki untuk menyesuaikan dengan perkembangan zaman (Hanushek, 2013).

Menurut Mayo dalam (Nugraha et al., 2018), sumber daya manusia atau human capital memiliki lima komponen yaitu individual capability, individual motivation, leadership, the organizational climate, dan work group effectiveness. Masing-masing komponen memiliki peranan yang berbeda dalam menciptakan human capital organisasi yang pada akhirnya menentukan nilai sebuah organisasi. Pentingnya keberadaan human capital di dalam sebuah organisasi, perlu diberikan perhatian khusus guna memberikan ruang kepada SDM untuk mengembangkan segala kemampuan yang ada pada dirinya sebagai upaya meningkatkan kinerja organisasi (Arcidiacono et al., 2010). Setiap SDM memiliki keunikan dan pengetahuan yang berbeda, sehingga organisasi dituntut untuk bisa memberikan ruang yang tepat bagi SDM-nya untuk berkembang.

Sumber daya manusia merupakan aset terpenting di dalam organisasi karena berfungsi sebagai pondasi utama (Kompaso \& Sridevi, 2010). Jika manusia yang terlibat dalam organisasi tersebut mampu memberikan kontribusi yang tidak hanya melalui pemikiran namun juga dalam bentuk kinerja yang sesuai dengan kompetensi yang dimiliki masing-masing maka organisasi tersebut akan terus berkembang dan tujuan dari sebuah organisasi tersebut dapat dicapai. Sumber daya manusia dalam organisasi bertugas merancang, menghasilkan, meneruskan melalui pelayanan-pelayanan sehingga dapat menciptakan kegiatan yang memberikan kontribusi tercapainya kinerja suatu organisasi.

Kompetensi inti organisasi merupakan kemampuan mengorganisir pekerjaan dan menyampaikan nilai; kompetensi dapat meliputi komunikasi, keterlibatan dan komitmen yang besar untuk bekerja sepanjang batas-batas organisasi. Kinerja suatu organisasi mencermikan seberapa efektif produk/jasa yang dihasilkan dan bagaimana organisasi dapat menyampaikan kepada pelanggan (Rich et al., 2010). Sumber daya manusia (SDM) dalam organisasi bertugas merancang, menghasilkan dan meneruskan melalui pelayanan-pelayanan (Mathis et al., 2017), oleh karena itu salah satu sasaran Manajemen Sumber Daya Manusia (MSDM) adalah menciptakan kegiatan yang memberikan kontribusi tercapainya superior performance.

Fakultas ilmu pendidikan merupakan fakultas tertua di Universitas Negeri Malang, dengan memiliki organisasi kemahasiswaan yang bergerak di tingkat fakultas dan jurusan. FIP berada pada tiga kampus yang berbeda, yakni dua kampus yang berbeda di daerah Kota Malang dan satu kampus di Kota Blitar. Organisasi 
kemahasiswan yang ada FIP UM terbagi menjadi Organisasi Pemerintah Mahasiswa (OPM) dan Organisasi Non Pemerintah Mahasiswa (ONPM), OPM di FIP UM mulai dari BEM Fakultas, Dewan Mahasiswa Fakultas, Himpunan Mahasiswa Jurusan dan KKM, sedangkan ONPM di FIP UM yakni Unit Aktivitas yang bergerak dibidang seni, olahraga, kepenulisan, dan keagamaan. Berdasarkan penelitian yang dilakukan oleh (Nugroho et al., 2018) motivasi mahasiswa dalam berorganisasi dipengaruhi oleh beberapa faktor yakni faktor keberhasilan, lingkungan, kemampuan, dan kepribadian. Salah satu faktor tersebut adalah kemampuan yang dimiliki oleh mahasiswa. Mahasiswa yang memiliki kemampuan yang tinggi dapat menjadi modal manusia yang unggul dalam suatu organisasi dan tentunya akan meningkatkan kinerja mahasiswa dalam berorganisasi serta organisasi itu sendiri.

Standar keberhasilan suatu organisasi dapat dilihat dari kemampuan yang dimiliki oleh setiap indvidu (Arcidiacono et al., 2010). Bagaimana individu tersebut bersosialisasi dan bekerja sama di sebuah organisasi human capital berperan penting karena merupakan modal utama yang dimiliki setiap individu. Seseorang yang memiliki pengetahuan dan keterampilan yang tinggi maka akan bermanfaat bagi organisasi. Namun juga harus disertai dengan komitmen yang tinggi pula, sebab jika tidak maka akan sia-sia kemampuan yang mereka miliki. Jadi harus terdapat keseimbangan antara keterampilan dan komitmen yang dimiliki. Keberhasilan tingkat kinerja organisasi dapat dipengaruhi oleh keberadaan sumber daya manusia organisasi sebagai human capital sehingga organisasi harus berupaya mengoptimalkan aset pengetahuan yang ada pada human capital (Ali \& Chaudhry, 2017; Fikri, 2017). Apabila human capital dapat dioptimalkan maka kinerja dalam organisasi akan meningkat. Oleh karena itu, penelitian ini bertujuan untuk mengetahui: (1) tingkat human capital organisasi mahasiswa, (2) tingkat kinerja organisasi mahasiswa, dan (3) hubungan human capital terhadap kinerja organisasi mahasiswa di lingkungan FIP UM.

\section{B. METODE}

Penelitian ini menggunakan pendekatan kuantitatif dengan rancangan penelitian yang bersifat deskriptif korelasional. Penelitian kuantitatif menurut Darmawan (2013) digunakan untuk menjabarkan fenomena atau kejadian sesuai apa yang terjadi saat penelitian dilaksanakan. Penelitian ini bersifat deskriptif sebab bertujuan untuk mendapatkan gambaran mengenai variabel yang diteliti, bersifat korelasional sebab penelitian ini bertujuan untuk mengetahui ada tidaknya hubungan antara dua variabel atau lebih. Hubungan antar variabel dapat dilihat pada Gambar 1.

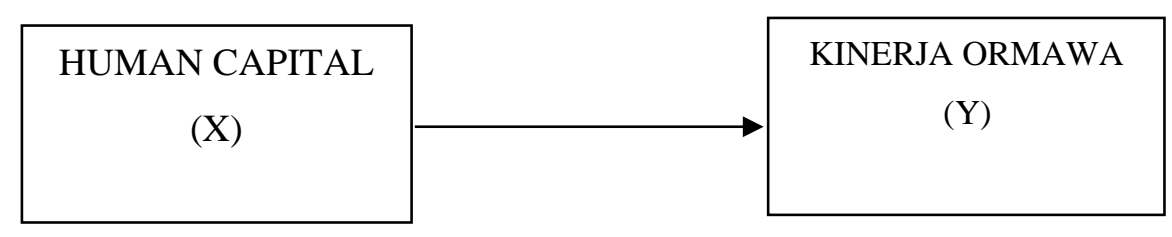

\section{Gambar.1 Hubungan Antar Variabel}

Instrumen penelitian yang disusun oleh peneliti, sebelum digunakan dalam penelitian terlebih dahulu dilakukan uji expert setelah mendapatkan masukan oleh expert peneliti melakukan revisi instrumen berdasarkan masukan expert untuk kemudian 
digunakan dalam pengumpulan data menggunakan kuesioner dengan bantuan google form dengan responden anggota organisasi mahasiswa yang ada di FIP UM. Populasi dalam penelitian ini berjumlah 250 orang. Sementara sampel penelitian yang digunakan dalam penelitian sejumlah 64 orang sampel. Penelitian ini menggunakan random sampling. Data yang digunakan dalam penelitian ini yakni menggunakan skala likert. Teknik analisis data yang digunakan yakni deskriptif korelasional. Uji korelasi dilakukan menggunakan Product Moment Pearson dengan bantuan program Statistical Package for Social Science for windows versi 24.0.

\section{HASIL}

\section{Human Capital Organisasi Kemahasiswaan}

Penerapan Human Capital di organisasi mahasiswa Fakultas Ilmu Pendidikan (FIP) UM tergolong cukup baik sebesar 56\%. Tergolong dalam kategori baik sebesar 27\%, kategori tidak baik sebesar 13\% dan kategori sangat baik 5\%. Berdasarkan analisis data di atas dapat diketahui, bahwa persentase tingkat penerapan Human Capital di organisasi mahasiswa Fakultas Ilmu Pendidikan (FIP) UM dalam kategori cukup baik, yakni sebesar 56\%. Hasil penelitian tersebut merupakan kumpulan dari indikator variabel penelitian yang diambil dari komponen human capital menurut Mayo dalam (Nugraha et al., 2018), yang meliputi individual capability, individual motivation, leadership, the organizational climate, and work group effectiveness.

\section{Tabel 1. Distribusi Frekuensi dan Persentase Human Capital}

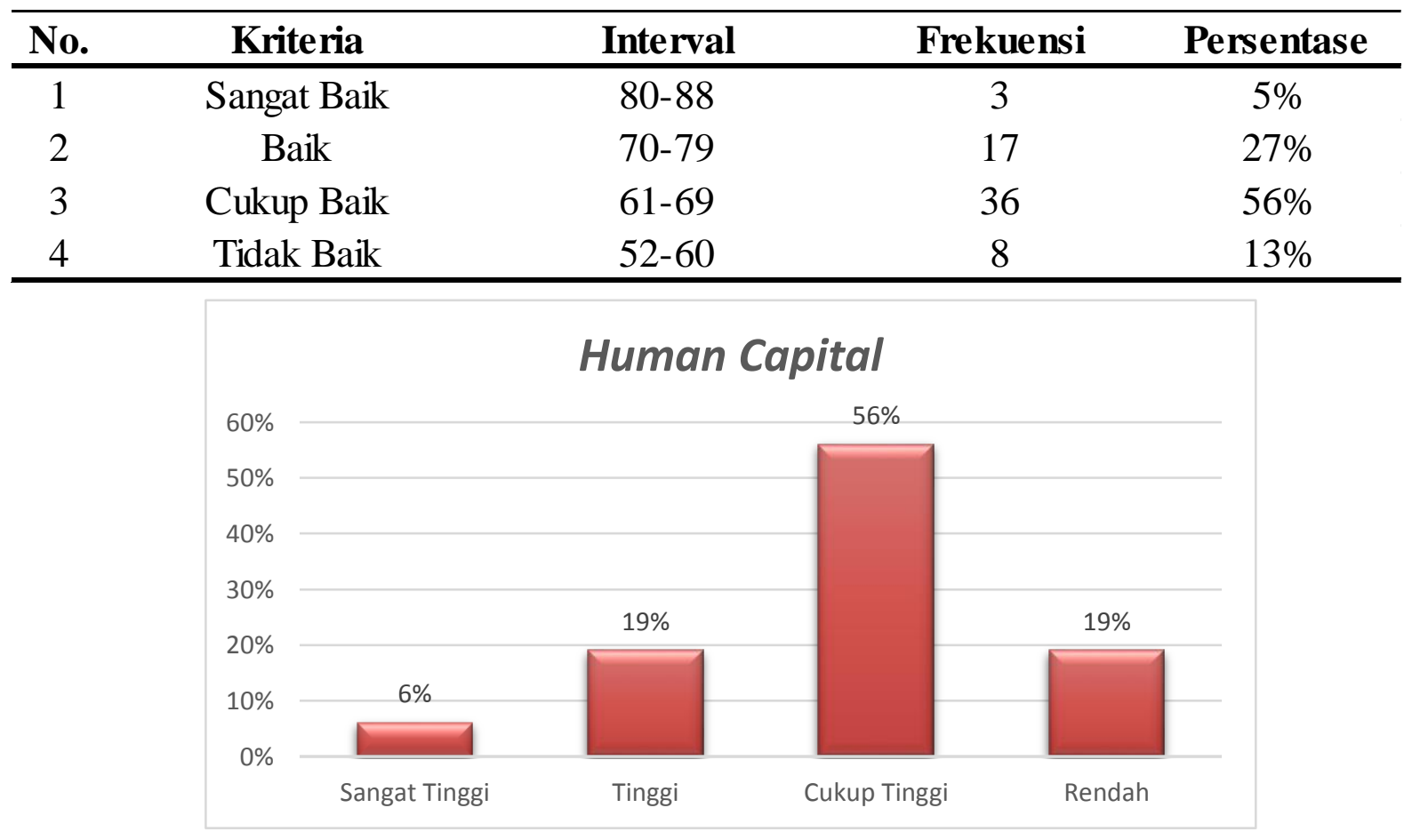

\section{Kinerja Organisasi Kemahasiswaan}

\section{Gambar 2. Diagram Persentase Human Capital}

Tingkat kinerja organisasi mahasiswa di Fakultas Ilmu Pendidikan (FIP) UM tergolong cukup tinggi sebesar 56\%. Tergolong dalam kategori tinggi sebesar 19\%. Kategori rendah sebesar 19\%, sementara kategori sangat tinggi sebesar 6\%. Berdasarkan 
analisis data di atas dapat diketahui, bahwa persentase tingkat kinerja organisasi mahasiswa di Fakultas Ilmu Pendidikan (FIP) UM dalam kategori cukup tinggi, yakni sebesar 56\%. Hasil penelitian tersebut merupakan kumpulan dari indikator variabel penelitian yang diambil dari dimensi dalam pengukuran kinerja organisasi yakni kualitas, kuantitas, penggunaan waktu dalam bekerja, kerjasama dengan orang lain dalam bekerja.

Tabel 2. Distribusi Frekuensi Kinerja Organisasi Mahasiswa

\begin{tabular}{ccccc}
\hline No. & Kriteria & Interval & Frekuensi & Persentase \\
\hline 1 & Sangat Tinggi & $48-52$ & 4 & $6 \%$ \\
2 & Tinggi & $43-47$ & 12 & $19 \%$ \\
3 & Cukup Tinggi & $38-42$ & 36 & $56 \%$ \\
4 & Rendah & $33-37$ & 12 & $19 \%$ \\
\hline
\end{tabular}

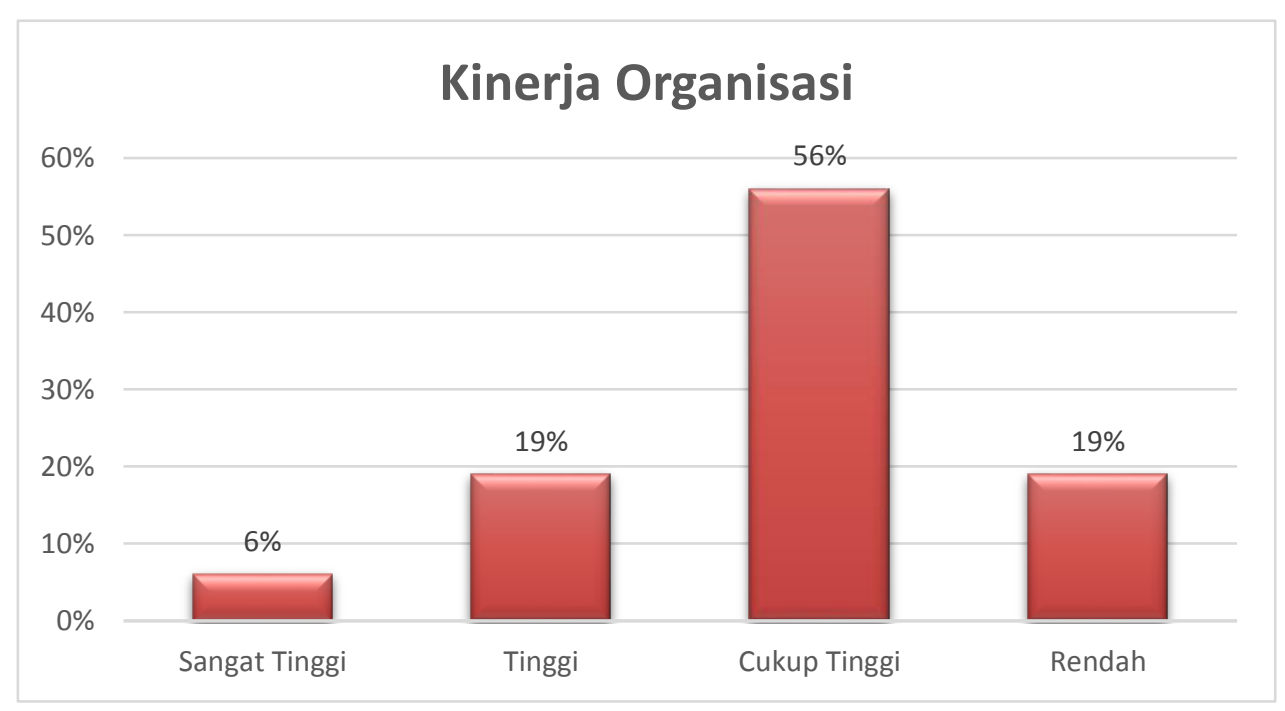

Gambar 3. Diagram Persentase Kinerja Organisasi

\section{Hubungan antara Human Capital dengan Kinerja Organisasi Mahasiswa}

Berdasarkan hasil perhitungan diperoleh rhitung sebesar 0,678 pada taraf signifikansi 5\% atau 0,5 dengan tanda ** (dua bintang) pada analisis korelasi Product Moment Pearson dengan menggunakan SPSS 24.0 for windows dan jumlah sampel 64 orang anggota organisasi mahasiswa. Kriteria pengujian dilakukan dengan cara membandingkan nilai probabilitas $(\mathrm{SIG})<0,05$, artinya $\mathrm{H}_{0}$ ditolak, yang berarti terdapat hubungan yang signifikan antara variabel $x$ dan variabel y (Adha et al., 2018). Pengujian hipotesis dapat dilihat pada Tabel 3.

\section{Tabel 3 Pengujian Hipotesis}

\begin{tabular}{lllll}
\hline Hipotesis & Hasil Uji & Sign & Hasil Pengujian \\
\hline $\begin{array}{l}\text { Ho: tidak ada hubungan antara } \\
\text { penerapan human capital dengan } \\
\text { kinerja organisasi mahasiswa }\end{array}$ & & 0.050 & h0 ditolak \\
\hline
\end{tabular}


Berdasarkan Tabel 3 dapat diketahui bahwa Ho ditolak, yang berarti Ha diterima artinya ada hubungan antara penerapan human capital dengan kinerja organisasi mahasiswa di Fakultas Ilmu Pendidikan (FIP) UM. Nilai hasil uji signifikansi berdasarkan pada Tabel 3 yang menunjukkan angka 0,000 artinya angka probabilitas $(\mathrm{SIG})<0,05$ ada hubungan antara kedua variabel yang signifikan. Hal ini menunjukan adanya hubungan yang signifikan antara dua variabel tersebut dan bersifat positif, yakni bila variabel Human Capital besar, maka variabel kinerja ormawa semakin besar pula.

Hal tersebut juga dibuktikan dengan beragam contoh kegiatan kemahasiswaan yang berhasil dilaksanakan oleh organisasi kemahasiswaan baik di tingkat jurusan maupun fakultas, contoh kegiatan tersebut antara lain; Penyelenggaraan seminar nasional dengan tema "persiapan pendidikan menghadapi era merdeka belajar" yang diselenggarakan oleh Himpunan Mahasiswa Jurusan Administrasi Pendidikan FIP UM pada tahun 2020; Penyelenggaraan Kompetisi Mahasiswa Tingkat Nasional dengan tema "optimalisasi daya saing generasi muda yang inovatif dan kreatif dalam menghadapi adaptasi kebiasaan baru" yang diselenggarakan oleh Badan Eksekutif Mahasiswa FIP UM pada tahun 2020; dan masih banyaklagi kegiatan yang lain. Selain itu salah satu organisasi kemahasiswaan di FIP UM juga pernah mendapatkan penghargaan sebagai "Ormawa of the year" yang di selenggarakan Universitas Negeri Malang pada tahun 2017, dan masih banyak lagi prestasi-prestasi yang lain.

\section{PEMBAHASAN}

\section{Human Capital Organisasi Kemahasiswaan}

Tingkat human capital pada organisasi mahasiswa di Fakultas Ilmu Pendidikan Universitas Negeri Malang yang tergolong cukup tinggi, hal ini menunjukkan bahwa human capital sudah tergolong cukup baik, penerapan human capital pada organisasi mahasiswa di Fakultas Ilmu Pendidikan mampu memberikan dampak terhadap kinerja organisasi. penerapan human capital yang baik dapat memberikan keuntungan bagi setiap organisasi. Misalnya saja untuk mengidentifikasi kinerja setiap anggota dan memberikan umpan balik kepada organisasi.

Human capital merupakan kombinasi dari tiga faktor (Fullan, 2014), yaitu: 1) karakter atau sifat yang dibawa ke pekerjaan, misalnya intelegensi, energi, sikap positif, keandalan, dan komitmen, 2) kemampuan seseorang untuk belajar, yaitu kecerdasan, imajinasi, kreatifitas dan bakat dan 3) motivasi untuk berbagi informasi dan pengetahuan, yaitu semangat tim dan orientasi tujuan. Endri (2010) mendefinisikan human capital merupakan kombinasi dari pengetahuan, keterampilan, inovasi dan kemampuan seseorang untuk menjalankan tugasnya sehingga dapat menciptakan suatu nilai untuk mencapai tujuan. Jadi dapat disimpulkan bahwa human capital merupakan tiga faktor kombinasi yaitu perilaku, keterampilan, dan motivasi yang digunakan di dalam sebuah organisasi guna mencapai tujuan yang telah ditetapkan.

Kelima komponen Human Capital adalah individual capability, individual motivation, the organization climate, workgroup effectiveness dan leadership (Elzaditya, 2018). Individual capability merupakan kecakapan yang dimiliki oleh seseorang yang berasal dari hasil proses belajar dan keturunan, individual motivation merupakan dorongan yang dimiliki oleh seseorang agar siap secara mental, fisik, situasi, dan tujuan pada saat bekerja. Leadership merupakan sikap yang dimiliki seseorang yang dipengaruhi dalam situasi tertentu dalam dan melalui proses komunikasi untuk mencapai tujuan tertentu. The 
organizational climate merupakan sistem nilai organisasi yang dianut oleh suatu organisasi yang nantinya akan mempengaruhi cara kerja dan perilaku anggota yang ada di organisasi tersebut. Workgroup effectiveness merupakan efektifitas tim kerja didasarkan pada hasil produktif dan kepuasan pribadi yang berkenaan dengan kemampuan tim untuk memenuhi kebutuhan dan mempertahankan anggota serta komitmen yang mereka miliki (Baron, 2011). Jadi individual capability, individual motivation, leadership, the organizational climate, and workgroup effectiveness ialah komponen yang ada di dalam human capital yang merupakan gabungan dari pengetahuan, keterampilan, inovasi dan kemampuan seseorang dalam menjalankan tugas dan tanggung jawab yang diberikan dan nantinya akan menghasilkan suatu nilai yang berguna untuk mencapai tujuan yang telah ditetapkan.

Komponen yang ada didalam human capital yang meliputi individual capability, individual motivation, leadership, the organizational climate, and workgroup effectiveness dapat menunjang atau membantu meningkatkan kinerja karyawan. Sesuai dengan pendapat Nalbantian et al dalam (Putri, 2013) mendefinisikan human capital sebagai persediaan dari kumpulan pengetahuan, keterampilan, pengalaman, kreativitas dan atribut pekerja lainnya dan berpendapat bahwa human capital juga mencakup memberi nilai pada setiap atribut ini serta menggunakan pengetahuan secara efektif untuk mengelola organisasi. Organisasi harus dapat melakukan peningkatan kualitas sumber daya manusia dalam menghadapi tantangan, dan juga untuk mencapai visi dan misi organisasi (Sukoco \& Prameswari, 2017). Human capital memandang manusia sebagai keseleruhan dari pengetahuan, keahlian dan keterampilan yang dimilikinya hal ini menjadikan manusia sebagai aset berharga dari organisasi (Odden, 2011).

\section{Kinerja Organisasi Kemahasiswaan}

Tingkat keefektifan kinerja organisasi mahasiswa di Fakultas Ilmu Pendidikan lingkungan Unversitas Negeri Malang tergolong cukup tinggi. Menunjukkan bahwa anggota setiap organisasi mahasiswa yang ada di Fakultas Ilmu Pendidikan dapat menyelesaikan tugasnya dengan cukup baik. Kinerja anggota didefinisikan sebagai hasil kerja secara kuantitas, kualitas dan ketepatan waktu yang dicapai seseorang karyawan dalam melaksanakan tugasnya sesuai tanggung jawab yang diberikan kepadanya (Kusuma \& Ardana, 2014). Kualifikasi kinerja organisasi di FIP tergolong cukup baik setiap anggota mampu mengerjakan segala sesuatu dengan cukup tepat waktu. Setiap anggota dapat menentukan dan mengatur setiap beban kerja, sehingga mampu menyelesaikan pekerjaan dengan cukup tepat waktu dan menghasilkan jumlah output yang besar.

Kinerja organisasi merupakan efektivitas yang mencakup tercapainya tujuan organisasi, efisiensi yang mempertimbangkan hubungan antara input dan output yang diperlukan untuk mencapai output, dan adaptasi yang merefleksikan kemampuan organisasi untuk beradaptasi dengan perubahan lingkungan (Rich et al., 2010; Ubaidillah et al., 2020). Kinerja suatu organisasi mencerminkan seberapa efektif produk/jasa yang dihasilkan dan bagaimana organisasi dapat menyampaikan kepada pelanggan. Sumber daya manusia (SDM) dalam organisasi bertugas merancang, menghasilkan dan meneruskan melalui pelayanan-pelayanan (Mathis et al., 2017) oleh karena itu salah satu sasaran Manajemen sumber daya manusia (MSDM) adalah menciptakan kegiatan yang memberikan kontribusi tercapainya kinerja yang tinggi. 
Pengukuran kinerja organisasi yang dikemukakan oleh Miner dalam (Jailani, 2012) yakni kualitas, kuantitas, penggunaan waktu dalam bekerja, kerjasama dengan orang lain dalam bekerja. Dapat disimpulkan bahwa kinerja organisasi merupakan perilaku yang melekat pada seseorang yang sesuai dengan peraturan yang ada. Kinerja organisasi merupakan sebuah pengukuran seberapa jauh suatu organisasi tersebut telah melaksanakan semua kegiatan pokok untuk mencapai visi dan misi atau sebagai gambaran hasil kinerja suatu organisasi dalam mencapai tujuan yang dipengaruhi oleh sumber daya yang dimiliki.

\section{Hubungan antara Human Capital dengan Kinerja Organisasi Mahasiswa}

Hasil penelitian yang dijabarkan menunjukkan kinerja organisasi kemahasiswaan dipengaruhi oleh variabel human capital. Istilah ini dapat dianggap sebagai hubungan sebab akibat. Dalam hal ini kinerja organisasi mahasiswa di Fakultas Ilmu Pendidikan dipengaruhi oleh terminologi human capital. Berdasarkan hasil penelitian yang didapatkan human capital berhubungan dengan peningkatkan kinerja organisasi kemahasiswaan di Fakultas Ilmu Pendidikan UM.

Pengukuran kinerja organisasi yang hanya diukur melalui pencapaian finansial, tidak merefleksikan daya saing yang sebenarnya dari organisasi dan belum mampu meramal kinerja organisasi di masa depan. Modal intelektual dan potensi inovasi merupakan kunci jangka panjang bagi "kestabilan" organisasi, dan bahwa manusia atau "human capital" merupakan sumber utama dari kedua asset tersebut (Fullan, 2014; Maisyaroh et al., 2020; Nurjanah, 2014). Peranan modal intelektual sangat berpengaruh terhadap kinerja anggota dan dalam jangka panjang akan mempengaruhi kinerja organisasi, karena modal intelektual dapat digunakan organisasi untuk menciptakan kinerja yang diharapkan, dan sebagai alat evaluasi kinerja anggota organisasi untuk menciptakan anggota yang survive terhadap kebutuhan organisasi ke depan (Kucharčíková et al., 2015). Modal intelektual merupakan potensi di masa depan yang merupakan kombinasi dari modal manusia dan potensi dari orang-orang dalam organisasi. Dengan demikian, modal intelektual merupakan aset yang tidak terlihat yang merupakan gabungan dari faktor manusia, proses dan pelanggan yang memberikan keunggulan kompetitif (Kasmawati, 2017).

Sehingga kinerja organisasi mahasiswa diharapkan memiliki pengaruh yang baik karena sebagai modal manusia untuk memperbaiki kualitas sumber daya manusia. Institusi Perguruan Tinggi menghadapi tantangan besar dalam banyak hal seperti perkembangan teknologi informasi, tingginya tuntutan kinerja, peningkatan pelayanan dan penyempurnaan fasilitas belajar mengajar serta penerimaan mahasiswa yang lebih berkualitas (Sunandar \& Imron, 2020). Hal ini sesuai dengan pernyataan Karpagam dalam (Amalia, R \& Yahya, 2016) yang menyatakan bahwa Perguruan tinggi menghadapi tantangan baru yaitu trend globalisasi, tantangan ekonomi baru, dan cepatnya pertumbuhan informasi dan teknologi untuk meningkatkan kinerjanya. Perguruan tinggi adalah salah satu organisasi terpenting dalam kehidupan berbangsa dan bernegara karena perguruan tinggi menghasilkan lulusan yang akan meneruskan tongkat estafet perjuangan pemerintah dan memajukan perekonomian negara sehingga tercipta negara yang makmur, aman dan tentram (Adha et al., 2020; Hanushek, 2013). Untuk dapat menghasilkan lulusan yang berkualitas perguruan tinggi haruslah 
berbenah diri sejalan dengan tuntutan jaman dalam meningkatkan kinerjanya (Amalia, R \& Yahya, 2016).

\section{E. KESIMPULAN}

Kinerja organisasi mahasiswa dalam terminologi human capital di Fakultas Ilmu Pendidikan Universitas Negeri Malang dinilai dapat mempengaruhi dari peningkatan kinerja. Berdasarkan hasil melalui pernyataan variabel-variabel dapat dikatakan bahwa penerapan human capital di organisasi kemahasiswaan tergolong cukup tinggi dan kinerja organisasi cukup tinggi. Berdasarkan analisis data ditemukan hubungan yang signifikan dan positif antara human capital dengan kinerja organisasi mahasiswa di tingkat Fakultas Ilmu Pendidikan Universitas Negeri Malang. Sehingga melalui organisasi mahasiswa di perguruan tinggi diharapkan menghasilkan lulusan yang berkualitas untuk bisa bersaing dan menghadapi tantangan di era sekarang ini, oleh karena itu perguruan tinggi harus dapat meningkatkan kinerjanya dengan maksimal.

Berdasarkan kesimpulan, peneliti dapat memberikan saran yakni, (1) mahasiswa diharapkan untuk mengikuti organisasi yang telah ada di perguruan tinggi masingmasing dengan harapan mahasiswa bisa mengembangkan diri dari suatu organisasi. Sehingga dengan berorganisasi mahasiswa memiliki peningkatan kinerja, (2) bagi peneliti lain hendaknya dapat mengembangkan penelitian ini dengan menemukan permasalahan atau kendala yang dialami dalam kinerja organisasi mahasiswa dengan terminologi human capital serta dapat mencari solusi dari permasalahan tersebut. Keterbatasan penelitian ini yakni lingkup penelitian yang hanya berada pada tingkat fakultas karena itu juga direkomendasikan pada peneliti lain untuk melakukan penelitian yang terkait dengan human capital organisasi kemahasiswaan di tingkat universitas atau melakukan perbandingan antara perguruan tinggi satu dengan yang lain.

\section{REFERENSI}

Adha, M. A., Ariyanti, N. S., Mustiningsih, Maisyaroh, \& Bafadal, I. (2020). Analysis of Success Factors Implementation of Computer-Based Management Information System in Higher Education. 1st International Conference on Information Technology and Education (ICITE 2020), 508(Icite), 80-85.

https://doi.org/https:/ / dx.doi.org/10.2991/assehr.k.201214.217

Adha, M. A., Mustiningsih, \& Maisyaroh. (2018). Hubungan Pelaksanaan Sistem Informasi Manajemen Berbasis Komputer dan Keefektifan Kinerja PNS Di Perguruan Tinggi. Jurnal Administrasi Dan Manajemen Pendidikan, 1(2), 124-131. https://doi.org/http:/ /dx.doi.org/10.17977/um027v1i22018p124

Ali, H., \& Chaudhry, I. S. (2017). Effect of human capital on organization performance : an analysis from service sector of Punjab, Pakistan. European Online Journal of Natural and Social Sciences, 6(3), 475-481.

Amalia, R \& Yahya, A. (2016). Pengaruh Sistem Kerja Terhadap Kinerja Perguruan Tinggi Dan Implikasinya Terhadap Kepercayaan Mahasiswa Universitas Syiah Kuala Banda Aceh. 10(1), 1-10. https://doi.org/10.13170/jp.10.1.3020

Arcidiacono, P., Bayer, P., \& Hizmo, A. (2010). Beyond Signaling and Human Capital: Education and the Revelation of Ability. American Economic Journal: Applied 
Economics, 2(4), 76-104. https:/ / doi.org/10.1257/app.2.4.76

Baron, A. (2011). Measuring human Capital. Strategic HR Review, 10(2), 30-35. https:// doi.org/10.1108/14754391111108338

Darmawan, D. (2013). Metode Penelitian Kuantitatif. Remaja Rosdakarya.

Elzaditya, D. (2018). Pengaruh Penerapan Human Capital dalam Pencapaian Target Program Peningkatan Produksi Padi di Kabupaten Tanggamus. Journal of Chemical Information and Modeling, 53(9), 1689-1699.

https:// doi.org/10.1017/CBO9781107415324.004

Endri. (2010). Peran Human Capital Dalam Meningkatkan Kinerja Perusahaan: Suatu Tinjauan Teoritis Dan Empiris. Jurnal Administrasi Bisnis Unpar, 6(2), 2342-2356.

Fikri, F. (2017). Pengaruh Human Capital (Modal Manusia) Terhadap Pertumbuhan Ekonomi Provinsi Jawa Timur. Jurnal Ilmiah Mahasiswa FEB Universitas Brawijaya, 5(2), 1-11.

Fullan, M. (2014). The Principal: Three Keys to Maximizing Impact. Journal of Catholic Education, 18(1), 208-211. https://doi.org/10.15365/joce.1801152014

Hanushek, E. A. (2013). Economic Growth in Developing Countries: The Role of Human Capital. Economics of Education Review, 37(C), 204-212.

https://doi.org/10.1016/j.econedurev.2013.04.005

Jailani, M. (2012). Kredibilitas Pemimpin Terhadap Kinerja Pegawai Dinas Pengendalian Lahan dan Tata Ruang Kabupaten Kutai Timur. Jurnal Paradigma, 1(3), 402-419.

Kasmawati, Y. (2017). Human Capital dan Kinerja Karyawan (Suatu Tinjauan Teoritis). Journal of Applied Business and Economics, 3(4), 265-280.

Kompaso, S. M., \& Sridevi, M. S. (2010). Employee Engagement: The Key to Improving Performance. International Journal of Business and Management, 5(12), 89-96. https://doi.org/10.5539/ijbm.v5n12p89

Kucharčíková, A., Tokarčíková, E., \& Blašková, M. (2015). Human Capital Management - Aspect of the Human Capital Efficiency in University Education. Procedia - Social and Behavioral Sciences. https:// doi.org/10.1016/j.sbspro.2015.02.332

Kusuma, I., \& Ardana, K. (2014). Pengaruh Penempatan dan Kompensasi Terhadap Kepuasan Kerja dan Kinerja Karyawan. E-Jurnal Manajemen Universitas Udayana, 3(7), 25-37.

Maisyaroh, Arifin, I., Ariyanti, N. S., \& Adha, M. A. (2020). The Mediating Role of Entrepreneurship Interest on the Effect of Entrepreneurship Education to Digital Startup Preparation in the Digital Age. 1st International Conference On Information Technology And Education (ICITE 2020) The, 508(Icite), 211-216.

https://doi.org/10.2991/assehr.k.201214.238

Marginson, S. (2019). Limitations of Human Capital Theory*. Studies in Higher Education, 44(2), 287-301. https:/ / doi.org/10.1080/03075079.2017.1359823

Mathis, R. L., Jackson, J. H., \& Meglich, P. A. (2017). Human Resource Management (15th Editi). Thomson South-Western.

Nugraha, P. C., Susilo, H., \& Aini, E. K. (2018). Pengaruh Human Capital Terhadap Kenerja Perusahaan. Administrasi Bisnis (JAB), 57(2), 180-189. 
Nugroho, H., Benty, D. D. N., \& Juharyanto. (2018). Analisis Faktor-Faktor Motivasi Mahasiswa Mengikuti Organisasi Kemahasiswaan. Jurnal Administrasi Dan Manajemen Pendidikan, 1(1), 107-116.

Nurjanah, S. (2014). Human Capital Dan Peranan Pemerintah Dalam Pendidikan. Econosains Jurnal Online Ekonomi Dan Pendidikan, 12(1), 83-90. https:/ / doi.org/10.21009/econosains.0121.04

Odden, A. R. (2011). Strategic Management of Human Capital in Education. Routledge.

Putri, N. K. (2013). Human Capital Role in The Success of Organization: The Employee is Investation. Jurnal Administrasi Dan Kebijakan Kesehatan, 11(2), 93-97.

Rich, B. L., Lepine, J. A., \& Crawford, E. R. (2010). Job Engagement: Antecedents and Effects on Job Performance. Academy of Management Journal, 53(3), 617-635. https://doi.org/10.5465/amj.2010.51468988

Sukoco, I., \& Prameswari, D. (2017). Human Capital Approach To Increasing Productivity of Human Resources Management. AdBispreneur, 2(1), 93-104. https:// doi.org/10.24198/adbispreneur.v2i1.12921

Sunandar, A., \& Imron, A. (2020). The Model of University Autonomy in Indonesia. Advances in Social Science, Education and Humanities Research, 400(Icream 2019), 440446. https://doi.org/10.2991/coema-19.2019.12

Tan, E. (2014). Human Capital Theory: A Holistic Criticism. Review of Educational Research, 84(3), 411-445. https:/ / doi.org/10.3102/0034654314532696

Ubaidillah, E., Gunawan, I., Adha, M. A., Ariyanti, N. S., \& Erviana, Y. (2020). Students Perception of Technology-Assisted Services and Readiness of Employee Digital Competencies in Covid-19 Pandemic Era. Proceedings of the 6th International Conference on Education and Technology (ICET 2020) Students, 151-156. https://doi.org/10.2991/assehr.k.201204.026 